\title{
Recent progress in application of carbon nanomaterials in laser desorption/ionization mass spectrometry
}

\author{
Jing Wang ${ }^{1}$ - Qian Liu ${ }^{1,2}$ • Yong Liang ${ }^{1}$ Guibin Jiang ${ }^{1,2}$
}

Received: 30 September 2015 /Revised: 27 November 2015 / Accepted: 7 December 2015 / Published online: 11 January 2016

(C) Springer-Verlag Berlin Heidelberg 2015

\begin{abstract}
Carbon nanomaterials have attracted great interest over past decades owing to their unique physical properties, versatile functionalization chemistry, and biological compatibility. In this article, we review recent progress in application of carbon nanomaterials in laser desorption/ionization mass spectrometry (LDI MS). Various types of carbon nanomaterials, including fullerenes, carbon nanotubes, graphene, carbon nanodots, nanodiamond, nanofibers, nanohorns, and their derivative forms, are involved. The applications of these materials as new matrices or probes in matrix-assisted or surface-enhanced laser desorption/ ionization mass spectrometry (MALDI or SELDI MS) are discussed. Finally, we summarize current challenges and give our perspectives on the future of applications of carbon nanomaterials in LDI MS.
\end{abstract}

Keywords Carbon nanomaterial $\cdot$ Fullerene $\cdot$ Nanotube Graphene $\cdot$ Laser desorption/ionization $\cdot$ Mass spectrometry

Published in the topical collection featuring Young Investigators in Analytical and Bioanalytical Science with guest editors S. Daunert, A. Baeumner, S. Deo, J. Ruiz Encinar, and L. Zhang.

Qian Liu

qianliu@rcees.ac.cn

1 Institute of Environment and Health, Jianghan University, Wuhan 430056, China

2 State Key Laboratory of Environmental Chemistry \& Ecotoxicology, Research Center for Eco-Environmental Sciences, Chinese Academy of Sciences, Beijing 100085, China

\section{Introduction}

Since its invention in the 1980s [1, 2], matrix-assisted laser desorption/ionization mass spectrometry (MALDI MS) has gained a wide range of applications in analysis of various types of compounds, such as polymers, proteins, peptides, and nucleic acids, etc. MALDI MS is a soft ionization technique, which uses a matrix for laser energy absorption and analyte desorption/ionization. The LDI can also be assisted by the surface of substrate materials, namely, surfaceassisted laser desorption/ionization (SALDI) [3]. Currently, the most widely used matrices are weak organic acids, such as $\alpha$-cyano-4-hydroxycinnamic acid (CHCA), sinapinic acid (SA), and 2,5-dihydroxybenzoic acid (DHB). The important advantages of MALDI MS include high throughput, high speed, wide mass range (up to $900 \mathrm{kDa}$ ), low sample consumption, and modest tolerance of buffer and salt contamination. However, it also suffers from some drawbacks. For example, the application of MALDI MS in analysis of small molecules $(\mathrm{Mw}<500 \mathrm{Da})$ is usually limited by serious matrix interference in low-mass regions. Its sensitivity also needs further improvement to satisfy the demand of trace analysis. In order to extend the application range and improve the sensitivity of MALDI MS, many efforts have been made by using new materials as matrices, such as graphite materials $[4,5]$, porous silicon [6], organic materials [7], and metallic nanoparticles $[8,9]$, etc.

Carbon nanomaterials consist of a large family of carbonbased materials, including fullerenes, carbon nanotubes (CNTs), graphene, carbon nanodots, nanodiamond, nanofibers, nanohorns, etc. These materials have attracted intensive interest in MALDI MS owing mainly to their strong optical absorption at laser wavelengths as well as other exceptional properties, which can efficiently assist the LDI process. They can also form homogeneous co-crystallization with analytes to 
afford little or no fragmentation. Thus, carbon nanomaterialbased MALDI matrices are usually also applicable for analysis of small molecules. In particular, carbon nanomaterials have shown great promise in surface-enhanced laser desorption/ionization mass spectrometry (SELDI MS). SELDI is a variant mode of MALDI [10]. It uses a probe for the purification, extraction, amplification, desorption, and ionization of the analytes. Carbon nanomaterials have been demonstrated to be an excellent class of sorbent materials for extraction and enrichment of a wide variety of analytes [11-13]. Thus, the capabilities of assisting both extraction and LDI processes make carbon nanomaterials particularly suitable as probes for SELDI MS.

The applications of carbon nanomaterials in LDI MS are now increasing rapidly, and these materials are expected to play more and more important roles in MS technology. Therefore, it is very necessary to publish a review article to summarize recent progress and guide future studies in this area. Some related reviews have been published on the application of nanomaterials in MS [11, 12, 14-17]. For example, Lei et al. [18] presented a broad overview on the application of nanomaterials in MS techniques. Guo et al. [19] reviewed the use of nanomaterials in LDI MS for biological applications. Li et al. [20] summarized recent progress in the application of nanomaterials in sample preparation for MS analysis of proteins. Liu et al. [21] discussed the application of nanomaterials in analysis of emerging chemical pollutants. Here we present a specific review of recent progress in the application of carbon nanomaterials in LDI MS. We select and discuss some representative applications rather than listing exhaustively all the related publications.

\section{Applications of carbon nanomaterials in LDI MS}

Carbon nanomaterials consist of a group of members with diverse morphologies and varied physical and chemical properties. Up to now, almost all members of carbon nanomaterials have been applied in LDI MS with different degrees of success. Table 1 lists selected applications mentioned in this review.

\section{Fullerenes}

Fullerenes are hollow spheres formed from $\mathrm{sp}^{2}$-hybridized carbon atoms. They have an extremely conjugated and electron-deficient alkene system. Fullerenes have been used as matrices in MALDI MS mainly owing to their strong optical absorption in the UV-near-infrared region.

Bare fullerenes The Willett group reported the first example of use of fullerene as a MALDI matrix in 1994 [22, 23]. Proteins such as cytochrome c (12 kDa) and bovine albumin (66 kDa) could been successfully analyzed with the method, but it suffered from low sensitivity and narrow detectable mass range as a result of poor dispersion of polar analytes in the nonpolar fullerene.

Fullerene derivatives The surface polarity and water dispersibility of fullerenes can be significantly increased by derivatization with polar functional groups. For instance, Shiea et al. [24] synthesized a water-soluble fullerene derivative, hexa(sulfonbutyl)fullerene $\left(\mathrm{C}_{60}\left[\left(\mathrm{CH}_{2}\right)_{4} \mathrm{SO}_{3}{ }^{-}\right]_{6}\right)$, and used it to selectively precipitate positively charged compounds and as a matrix in MALDI MS detection. Vallant et al. [25] reported the use of [60]fullerene derivatives (dioctadecyl methano[60]fullerene, [60]fullerenoacetic acid, and iminodiacetic acid-[60]fullerene) as material-enhanced laser desorption/ionization (MELDI) carrier materials for the selective enrichment of low-mass peptides and proteins and their analysis with MALDI-time-of-flight (TOF) MS. MELDI is considered as a refinement of SELDI, which includes particle morphology beyond surface chemistry of support materials to affect the MS peak patterns, thereby multiplying the amount of data for screening of biological samples. By using fullerene derivatives as MELDI supports, they provided an approach for biomarker identification of bound analytes in the low-mass range ( $m / z$ 1000-4000).

Fullerene-silica composites More frequently, fullerenes were used after binding to a support material, e.g., silica. Vallant et al. [26] synthesized C60-fullerene-bound silica for solid-phase extraction (SPE) of biomolecules. Böddi et al. [27] reported the use of fullerene, octadecyl, and triaconthyl silica for SPE of tryptic peptides obtained from unmodified and in vitro glycated human serum albumin and fibrinogen. They found that fullerene-silica with a pore size of $30 \mathrm{~nm}$ showed better recoveries at low peptide concentrations than C18- and C30-modified silicas. Szabo et al. [28] also developed fullerene-silica materials as matrices for the analysis of biologically important small molecules. The fullerene molecules were immobilized at the surface of different pore sized silica gels. They found that both the pore size and surface area affected the LDI process: the large pores can make the analytes desorb easily; the high surface area can facilitate the transfer of laser energy from the fullerenes to the analytes. These derivative fullerenes were useful for the measurement of small molecules at the low picomole level while eliminating the matrix background interference.

Chen et al. [29] reported the use of C60 fullerenefunctionalized magnetic silica (C60-f-MS) microspheres for the enrichment of trace levels of peptides in tryptic protein digest and human urine using MALDI-TOF MS. The C60f-MS microspheres were prepared by coating magnetite particles with silica microspheres via a sol-gel approach (Fig. 1a). 3-(Trimethoxysilyl)propyl methacrylate (MPS) was used to link C60 to the surface of the magnetic silica microspheres. 
Table 1 Applications of carbon nanomaterials in LDI MS

\begin{tabular}{|c|c|c|c|c|}
\hline Carbon nanomaterial & Analyte & Sample matrix & LOD & References \\
\hline Fullerenes C60 & $\begin{array}{l}\text { Insulin, cytochrome } \mathrm{c} \text { (Cyt } \mathrm{C}) \text {, and } \\
\text { bovine serum albumin (BSA) }\end{array}$ & Water & $\begin{array}{l}0.2 \text { fmol (for insulin), } \\
8 \text { fmol (for Cyt C), } \\
2 \text { fmol (for BSA) }\end{array}$ & {$[23]$} \\
\hline Hexa(sulfonbutyl)fullerene & $\begin{array}{l}\text { Positively charged surfactants, amino } \\
\text { acids, peptides, and proteins }\end{array}$ & $\begin{array}{l}\text { Commercial conditioner } \\
\text { solution, trypsin-digested } \\
\text { protein solution, and } \\
\text { biological fluids }\end{array}$ & - & {$[24]$} \\
\hline $\begin{array}{l}\text { Dioctadecyl } \\
\text { methano[60]fullerene, } \\
\text { [60]fullerenoacetic acid, } \\
\text { and IDA-[60]fullerene }\end{array}$ & Proteins and peptides & Human serum & - & {$[25]$} \\
\hline C60-aminosilica & $\begin{array}{l}\text { Peptides, phosphopeptides, flavonoids, } \\
\text { and proteins }\end{array}$ & $\begin{array}{l}\text { Phosphate buffer solution } \\
\text { (PBS) }\end{array}$ & - & {$[26]$} \\
\hline C60-aminopropylsilica & Phosphopeptides & Water and low-fat milk & - & {$[27]$} \\
\hline Fullerene-silica & Polymers, amino acids, and proteins & Deionized water & - & {$[28]$} \\
\hline $\begin{array}{l}\text { C60-functionalized magnetic } \\
\text { silica microsphere } \\
\text { (C60-f-MS microspheres) }\end{array}$ & Peptides/proteins & Water and human urine & $0.2 \mathrm{ng} \mu \mathrm{L}^{-1}$ (for Cyt C) & [29] \\
\hline C60-fullerene & Uranium & Doubly distilled water & $\sim 50 \mathrm{fmol}$ & {$[30]$} \\
\hline $\begin{array}{l}\text { Mixture of fullerenes } \\
(\mathrm{C} 60 / \mathrm{C} 70)\end{array}$ & Organometallic compounds & Water & - & {$[31]$} \\
\hline Carbon nanotubes (CNTs) & $\begin{array}{l}\text { Peptides, organic compounds, } \\
\beta \text { - cyclodextrin, and } N \alpha \text {-benzoyl-L- } \\
\text { arginine ethylester hydrochloride } \\
\text { (BAEE) }\end{array}$ & Water & $\sim 50$ amol (for BAEE) & {$[33]$} \\
\hline $\begin{array}{l}\text { Multiwalled carbon nanotubes } \\
\text { (MWCNTs) }\end{array}$ & $\begin{array}{l}\text { Eicosanoic acid (C20:0), docosanoic acid } \\
(\mathrm{C} 22: 0) \text {, tetracosanoic acid (C24:0) } \\
\text { and hexacosanoic acid (C26:0) }\end{array}$ & Plasma & $0.5-1 \mu \mathrm{g} \mathrm{mL}^{-1}$ & {$[34]$} \\
\hline $\begin{array}{l}\text { Oxidized carbon nanotubes } \\
\text { (oxidized CNTs) }\end{array}$ & $\begin{array}{l}\text { Neutral oligosaccharides, peptides, } \\
\text { and insulin }\end{array}$ & Water & $\begin{array}{l}10 \mathrm{fmol} \mathrm{mL}^{-1} \text { (for xylose) } \\
300 \mathrm{fmol} \text { (for insulin) }\end{array}$ & {$[47]$} \\
\hline Oxidized CNTs & $\begin{array}{l}\text { Organotin, organoarsenic, } \\
\text { organophosphate, organomecury, } \\
\text { alkyl phenol and bisphenol A (BPA), } \\
\text { polycyclic aromatic hydrocarbons } \\
\text { (PAHs), anilines, atrazine derivatives, } \\
\text { naphthol derivatives, chlormequat } \\
\text { chloride, diquat, paraquat, humic acid, } \\
\text { and decabromodiphenyl oxide } \\
\text { (BDE209) }\end{array}$ & $\begin{array}{l}\text { Chinese traditional medicines, } \\
\text { seawater, wastewater, } \\
\text { and tap water }\end{array}$ & $0.5 \mathrm{pg}$ (for paraquat) & [48] \\
\hline $\begin{array}{l}\text { Polystyrene/oxidized carbon } \\
\text { nanotubes (PS/OCNTs) } \\
\text { film }\end{array}$ & $\begin{array}{l}\text { Benzo }[a] \text { pyrene }(\mathrm{BaP}) \text { and } \\
\text { 1-hydroxypyrene (1-OHP) }\end{array}$ & Water and urine & $\begin{array}{l}\left.<0.1 \mathrm{ng} \mathrm{mL}^{-1} \text { (for } \mathrm{BaP}\right) \\
<0.5 \mathrm{ng} \mathrm{mL}^{-1} \text { (for 1-OHP) }\end{array}$ & {$[58]$} \\
\hline $\begin{array}{l}\text { Magnetite/oxidized carbon } \\
\text { nanotube composite } \\
\mathrm{Fe}_{3} \mathrm{O}_{4} @ \mathrm{SiO}_{2} / \mathrm{OCNT}\end{array}$ & $\mathrm{BaP}$ & Water & $2 \mu \mathrm{g} \mathrm{L}^{-1}$ & {$[59]$} \\
\hline Graphene & $\begin{array}{l}\text { Amino acids, polyamines, anticancer } \\
\text { drugs, nucleosides, and steroids }\end{array}$ & Water & $0.2 \mu \mathrm{M}$ (for squalene) & {$[63]$} \\
\hline Graphene nanoflakes & Lipids & PBS & - & {$[64]$} \\
\hline Few layer graphene (FLG) & $\begin{array}{l}\text { Polyethylene glycol (PEG, } 1000 \mathrm{Da}) \\
\text { and poly(methyl methacrylate) } \\
\text { (PMMA, } 650 \mathrm{Da})\end{array}$ & Water & - & {$[65]$} \\
\hline Graphene & Cyt $\mathrm{C}$ and ssDNA & PBS & $\begin{array}{l}1 \text { pM (for Cyt C); } \\
100 \text { fM (for ssDNA) }\end{array}$ & {$[66]$} \\
\hline $\begin{array}{l}\text { Nanosized graphene oxide } \\
\text { (NGO) }\end{array}$ & $\begin{array}{l}\text { Cellobiose, Leu-enkephaline, glutamine, } \\
\text { glutathione, lysine, mannitol, } \\
\text { phenylalanine, serine, } \\
\text { benzoyldibenzo- } p \text {-dioxin (BDPD), } \\
\text { BaP, and perfluorobutyric acid (PBA) }\end{array}$ & Water & $\begin{array}{l}\text { BDPD: } 15 \mathrm{fg} \\
\text { BaP: } 150 \mathrm{fg} \\
\text { PBA: } 15 \mathrm{pg}\end{array}$ & [83] \\
\hline $\begin{array}{l}\text { Acid-oxidized graphene } \\
\text { (AOG) }\end{array}$ & $\begin{array}{l}\text { Organochlorine pesticide (PCP), } \\
\text { endocrine disrupter (E2), brominated }\end{array}$ & Water & $\begin{array}{l}\text { PCP: } 60 \mathrm{fg} \\
\text { E2: } 0.25 \mathrm{ng} \\
\text { BDE-47: } 0.5 \mathrm{ng}\end{array}$ & {$[84]$} \\
\hline
\end{tabular}


Table 1 (continued)

\begin{tabular}{|c|c|c|c|c|}
\hline Carbon nanomaterial & Analyte & Sample matrix & LOD & References \\
\hline & $\begin{array}{l}\text { flame retardants (BDE-47), } \\
\text { and perfluorochemical (PFOS) }\end{array}$ & & PFOS: $10 \mathrm{fg}$ & \\
\hline AOG & $\begin{array}{l}\text { PFOS, brominated flame retardants } \\
\text { (BDE-47 and TBBPA), E2, PCP, } \\
\text { industrial additive (BPS), linear } \\
\text { surfactants (CTAB and TTAB), } \\
\text { aromatic surfactants (HDBAC, } \\
\text { TDBAC, and DDBAC), } \\
\text { and inorganic As }\end{array}$ & $\begin{array}{l}\text { Human serum, urine, } \\
\text { and river water }\end{array}$ & $\begin{array}{l}\text { PFOS: } 10 \mathrm{pg} \mathrm{mL}^{-1} \\
\text { TBBPA: } 1 \times 10^{4} \mathrm{pg} \mathrm{mL}^{-1} \\
\text { E2: } 50 \mathrm{pg} \mathrm{mL}^{-1} \\
\text { BDE-47: } 0.5 \mathrm{pg} \mathrm{mL}^{-1} \\
\text { BPS: } 100 \mathrm{pg} \mathrm{mL}^{-1} \\
\text { PCP:0.1 pg mL } \\
\text { As }{ }^{-1}: 1 \times 10^{4} \mathrm{pg} \mathrm{mL}^{-1} \\
\text { CTAB, TTAB: } 10 \mathrm{pg} \mathrm{mL}^{-1} \\
\text { HDBAC, DDBAC, } \\
\text { TDBAC: } 50 \mathrm{pg} \mathrm{mL}^{-1}\end{array}$ & {$[85]$} \\
\hline $\begin{array}{l}\text { Antibody-functionalized } \\
\text { graphene oxide } \\
\text { nanoribbons } \\
\text { (GONR-PEG-Ab) }\end{array}$ & Chloramphenicol & $\begin{array}{l}\text { River water and human } \\
\text { serum }\end{array}$ & $10 \mathrm{pg} \mathrm{mL}^{-1}$ & {$[86]$} \\
\hline $\begin{array}{l}\text { 1-Pyrenebutyryl chloride } \\
\text { functionalized graphene } \\
\text { oxide (PCGO) }\end{array}$ & Glycans & $\begin{array}{l}\text { Ammonium bicarbonate } \\
\text { buffer }\end{array}$ & $<10 \mathrm{ng}$ & {$[96]$} \\
\hline $\begin{array}{l}\text { Graphene-encapsulated } \\
\text { magnetic microspheres } \\
\left(\mathrm{Fe}_{3} \mathrm{O}_{4} @ \mathrm{SiO}_{2} @ \mathrm{G}\right)\end{array}$ & $\begin{array}{l}\text { Cyt C, myoglobin (Myo), } \\
\beta \text {-lactoglobulin ( } \beta \text {-Lac) }\end{array}$ & Water and human saliva & $3.8-68 \mathrm{fmol}$ & [112] \\
\hline $\begin{array}{l}\text { Polydopamine-coated } \\
\text { graphene and } \\
\text { functionalized with } \\
\text { titanium ions } \\
\left(\mathrm{Ti}^{4+}-\mathrm{G} @ \mathrm{PD}\right)\end{array}$ & Phosphopeptides & $\begin{array}{l}\text { Human serum and standard } \\
\text { peptide mixtures }\end{array}$ & $1 \mathrm{fmol}$ & [120] \\
\hline Nanodiamond & Proteins & $\begin{array}{l}\text { Ammonium bicarbonate } \\
\text { buffer }\end{array}$ & $\begin{array}{l}<125 \mathrm{pM} \\
\quad \text { (for Arg-vasopressin); } \\
\quad<2 \mathrm{pM} \text { (for Myo) }\end{array}$ & [121] \\
\hline Diamond nanopowder & Phosphopeptides & $\begin{array}{l}\text { Human serum, egg yolk, } \\
\text { and non-fat milk }\end{array}$ & $<100 \mathrm{fmol}$ & [122] \\
\hline $\begin{array}{l}\text { Derivatized graphitic } \\
\text { nanofibers (GNF) }\end{array}$ & Peptides and proteins & Human serum & $50 \mathrm{fmol} \mu \mathrm{L}^{-1}$ (for insulin) & [123] \\
\hline Carbon nanodots & Glucose and uric acid & Human serum and urine & $\begin{array}{l}0.2 \text { fmol } \\
\text { (for octadecanoicacid); } \\
10 \text { fmol (for glucose) }\end{array}$ & [124] \\
\hline Carbon dots & $\begin{array}{l}\text { Anti-inflammatory drug } \\
\text { mefenamic acid }\end{array}$ & Serum & $\begin{array}{l}0.51 \mathrm{ng} \text { in positive mode and } \\
0.46 \mathrm{ng} \text { in negative mode }\end{array}$ & {$[125]$} \\
\hline $\begin{array}{l}\text { Functional single-walled } \\
\text { carbon nanohorns } \\
\text { (SWNHs) }\end{array}$ & $\begin{array}{l}\text { Peptides, amino acids, fatty acids, } \\
\text { and adenosine triphosphate (ATP) }\end{array}$ & Urine & $1.0 \mu \mathrm{M}$ (for ATP) & {$[126]$} \\
\hline
\end{tabular}

- not reported

Then, C60-f-MS microspheres were obtained by using 2,2azobisisobutyronitrile (AIBN) as an initiator to trigger the polymerization with $\mathrm{C} 60$. Figure $1 \mathrm{~b}$ shows the procedures for the enrichment of peptides by C60-f-MS microspheres and subsequent MALDI-TOF MS detection. With the aid of an external magnetic field, the captured peptides can be separated from the complex samples and enriched for the subsequent MS detection. The process of enrichment was rapid ( $\sim 5 \mathrm{~min})$, convenient, and efficient.

In addition, fullerene matrices have also been used for detection of trace uranium [30] and organometallic compounds by MALDI MS [31].

\section{Carbon nanotubes}

Since being discovered by Iijima [32] in 1991, CNTs have gained tremendous applications in various fields owing to the unique dimension, large surface area, hollow and nanosized layered structures, high mechanical strength, and remarkable electrical, physical, and chemical properties. CNTs have also been demonstrated to be useful matrices for MALDI MS analysis in which CNTs serve as both laser radiation receptor and energy transporter for desorption/ionization of analytes with little or no matrix ion interference. 
Fig. 1 a Synthesis of C60functionalized magnetic silica microspheres. b Schematic of a fast and convenient enrichment protocol for MALDI-TOF MS analysis

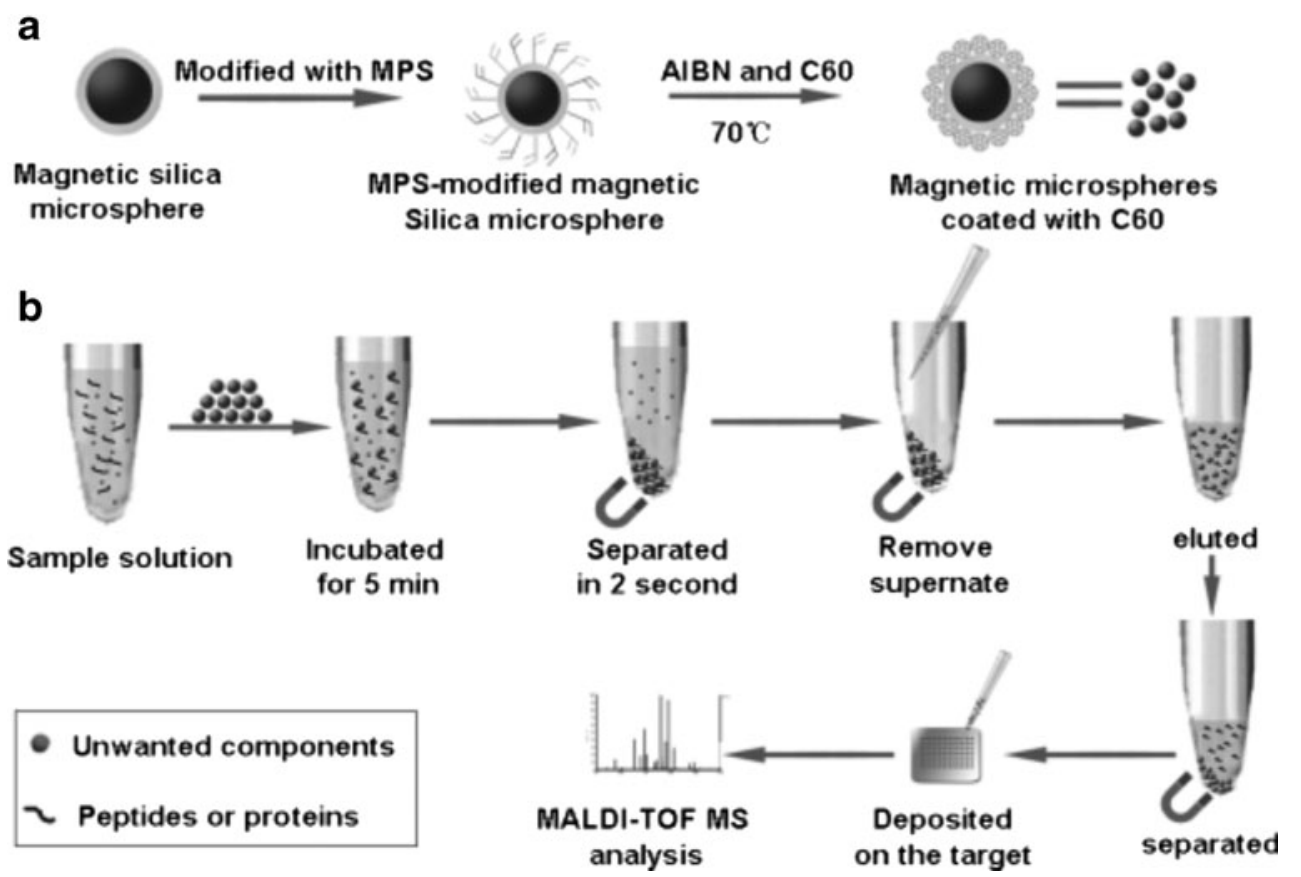

Bare CNTs Xu et al. [33] reported the use of CNTs as matrix in MALDI MS for analysis of small biomolecules. The sample solutions were dropped onto the CNTs on the target plate, and CNTs acted as a matrix to trap the analyte molecules. CNTs could greatly simplify sample preparation procedures, reduce background interference, and improve sensitivity. The method was applied to analysis of peptides, organic compounds, and $\beta$-cyclodextrin. However, the poor solubility of pristine CNTs in water or organic solvent made them difficult to deposit onto the sample target and to form a homogeneous layer with analytes, which led to relatively poor reproducibility and low resolution of analytes. Moreover, CNTs might not have been tightly trapped on the sample target and therefore might easily have escaped from the target under vacuum to cause contamination of the ion source.

To improve the sensitivity, Hsu et al. [34] described a screening assay of very long chain fatty acids (VLCFAs) in human plasma with multiwalled CNTs (MWCNTs) as a SELDI MS probe. In this study, MWCNTs acted as both adsorbent for enrichment of VLCFA derivatives and as matrix for MALDI MS analysis. This approach showed advantages such as pre-purification and concentration of samples without eluting and evaporation and low background peak interference in low-mass range.

CNTs with different dimensions and immobilization methods have also been used as matrices for analysis of other types of compounds, such as carbohydrates and amino acids [35-40].

Oxidized CNTs To improve the dispersibility of CNTs in solution and on the MALDI target, CNTs can be chemically oxidized to introduce polar groups at the surface [41-46]. Ren et al. [47] developed oxidized CNTs as a MALDI matrix. After oxidization, hydroxyl and carboxyl groups were introduced onto the CNTs. Thus, oxidized CNTs generated better dispersion of analytes and reproducibility than pristine CNTs in MALDI MS analysis. In addition, the ionization efficiency of analytes was improved because the hydroxyl and carboxyl groups at the CNTs surface provided basic sites to which a proton can attach. Meanwhile, the obtained spectra showed low matrix background over a wide mass range.

Hu et al. [48] also introduced oxidized CNTs as a matrix for analysis of low-mass compounds in environmental samples. To evaluate the validity of this method, they detected a number of environmentally meaningful chemicals, including organotin, organoarsenic, organophosphate, organomecury, alkyl phenols, polycyclic aromatic hydrocarbons (PAHs), aniline and its derivatives, atrazine derivatives, naphthol derivatives, humic acid, etc. They achieved simultaneous measurement of multiple polar low-mass compounds in environmental samples with high sensitivity. Compared with pristine CNTs, carboxylic groups at the surface of oxidized CNTs not only provide additional proton sources but also increase the surface polarity and solubility of the CNTs. The homogeneous distribution and adsorption on the MALDI plate can also avoid the electric discharge and contamination of the ion source, enhance the efficiency of LDI, and improve the reproducibility of peak intensities.

Functional CNTs and CNT-based composite materials CNTs can be modified with functional groups or integrated with other materials to achieve better selectivity, sensitivity, or to simplify the analytical procedures. These functional groups or materials include organic ligands [49, 50], graphene [51], 
nanoparticles [52, 53], dendrimers [54], SA [55], magnetic materials [53, 56], and polyelectrolytes [57].

$\mathrm{He}$ et al. [58] reported polystyrene/oxidized CNTs (PS/ OCNTs) film as both adsorbent in thin-film microextraction (TFME) and MALDI matrix to quantitatively determine benzo $[a]$ pyrene $(\mathrm{BaP})$ in environmental water and 1 hydroxypyrene (1-OHP) in urine samples by MALDI MS. $\mathrm{BaP}$ and 1-OHP could be detected at a concentration of $50 \mathrm{pg} / \mathrm{mL}$ and $500 \mathrm{pg} / \mathrm{mL}$, respectively. After extraction, the PS/OCNTs film was directly fixed on a MALDI plate for analysis without any extra desorption process, which could avoid possible loss of analyte. The procedures are shown in Fig. 2.

Li et al. [59] investigated magnetite/oxidized CNT composite $\left(\mathrm{Fe}_{3} \mathrm{O}_{4} @ \mathrm{SiO}_{2} / \mathrm{OCNT}\right)$ as a magnetic SPE sorbent and a matrix for the MALDI MS detection of BaP. They compared five types of carbon-based materials, graphene, graphene oxide (GO), CNT, oxidized CNT (OCNT), and C60. They found that OCNT showed the highest desorption/ionization efficiency and $\mathrm{S} / \mathrm{N}$ ratio among the studied materials owing to the abundant $\pi$-conjugated networks and the residual oxygenated functional groups of OCNT. Because of the strong $\pi-\pi$ interaction between OCNT and $\mathrm{BaP}, \mathrm{Fe}_{3} \mathrm{O}_{4} @ \mathrm{SiO}_{2} / \mathrm{OCNT}$ can also act as a good SPE sorbent for selective enrichment of $\mathrm{BaP}$ from both organic solvent and aqueous solution.

\section{Graphene}

Graphene is a two-dimensional, single-layered, and $\mathrm{sp}^{2}$-hybridized carbon sheet with a hexagonal packed structure. Its applications are exponentially increasing in various fields since its preparation by Novoselov and Geim in 2004 [60]. Owing to the unique structure, graphene shows many exceptional physical and chemical properties, such as ultrahigh surface area, high thermal conductivity, excellent optical transparency, etc. Similar to CNTs, graphene has also emerged as an excellent matrix or adsorbent for LDI MS owing to its strong optical absorption and energy transfer capability. Notably, although it appeared later, graphene has gained more applications than fullerene and CNTs in LDI MS, probably because of its easy preparation from graphite by chemical methods and facile functionalization via graphene oxide (GO) $[61,62]$.

Pure graphene Dong et al. [63] utilized graphene as a matrix in MALDI-TOF MS for the analysis of small molecular compounds, such as amino acids, polyamines, steroids, anticancer drugs, and nucleosides. Hua et al. [64] demonstrated graphene nanoflakes as a matrix for the analysis of cancer cell and cancer stem cell lipids. In this study, graphene nanoflakes produced a noise-free and good quality mass spectrum for the lipid extracts obtained from normal breast, cancer, and cancer stem cells. Cho et al. [65] employed fewlayered graphene (FLG) as a matrix for the analysis of low molecular weight polymers, polar polyethylene glycol (PEG) of $1000 \mathrm{Da}$, and nonpolar polymethylmethacrylate (PMMA) of $650 \mathrm{Da}$. High quality MS spectra with low background interference were obtained without any extra sampling procedures.

Compared with conventional organic matrices, graphene as a new matrix shows several advantages:

1. Simple sample preparation procedures

2. Elimination of the fragmentation of analytes

3. High efficiency in analyte desorption/ionization

4. Good reproducibility of peak intensities for analytes

5. High salt tolerance, etc.
Fig. 2 Schematic of the TFME technique coupled with MALDITOF MS analysis using electrospun PS/OCNTs film

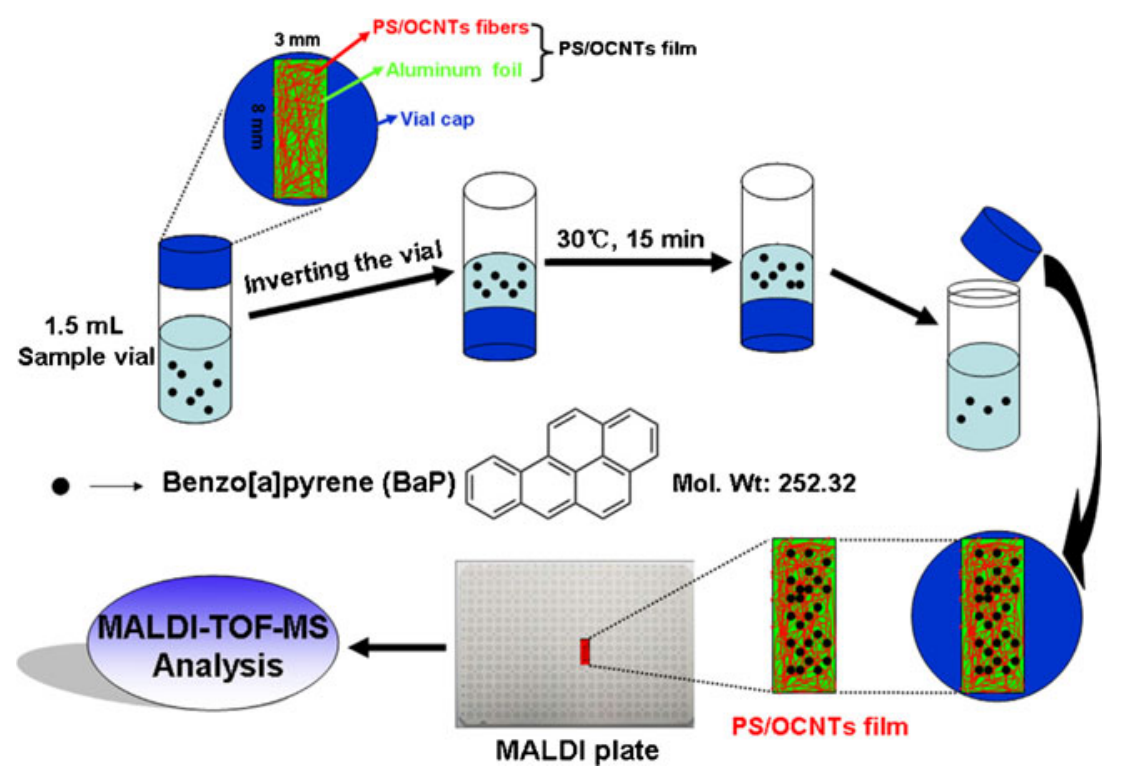


Graphene has also emerged as a superior SELDI probe because it can act as both a highly efficient adsorbent and effective MALDI matrix for the target analytes. Tang et al. [66] reported graphene as an ultrahigh efficiency SELDI probe for single-stranded DNA and proteins. The binding forces of graphene with biomolecules such as hydrophobic and $\pi-\pi$ interactions improved the efficiency of extraction and sensitivity of detection. The limit of detection (LOD) was $100 \mathrm{fM}$ for DNA and $1 \mathrm{pM}$ for protein.

In addition, pure graphene as a matrix has also been successfully applied to the LDI MS analysis of polymers [67], drugs [68], biomolecules [69, 70], organic pollutants [71-73], fatty acids [69, 74], active ingredients in herbs [75-77], metals and metal-organic complexes [78, 79], and glycan [80].

GO Pristine graphene may suffer from aggregation, which can significantly impair the LDI efficiency. Like oxidized CNTs, chemical oxidation can improve the water dispersibility and prevent the aggregation of the material. Notably, GO is easier to obtain than oxidized CNTs because it is actually an intermediate in the synthesis of graphene from graphite by chemical methods. Therefore, a number of papers have reported the application of GO as a matrix or a probe for MALDI or SELDI MS [66, 73-75, 81-83]. Whether graphene or GO shows better performance in LDI MS seems to be associated with the nature of the target analytes [66, 73-75]. Kim and Min [83] showed that the lateral size of GO played an important role in affecting its performance in MALDI MS. Small GO sheets were more stable to resist fragmentation under laser irradiation than large GO sheets.

Liu et al. $[84,85]$ reported the synthesis and application of nitric acid-oxidized graphene (AOG) as a MALDI matrix. The AOG had excellent water dispersibility to prevent the aggregation in solution or on the MALDI target; meanwhile, they found that the oxidation sites were mainly located at the edges of the AOG sheets, thereby maintaining the intactness of the $\pi$-electron conjugation structure of AOG to obtain high performance in LDI processes. AOG yielded significantly higher MS signals than graphene, GO, and CHCA in detection of nonpolar compounds.

Liu et al. [86] also demonstrated the use of graphene oxide nanoribbons (GONRs), elongated strips of graphene with high length-to-width ratio and straight edges, as a SELDI probe for simultaneous detection of multiple small molecules and profiling of small molecules in complex environmental samples (Fig. 3b). GONRs were prepared by chemical oxidation which resulted in longitudinal unzipping of CNTs (Fig. 3a). GONRs showed good water dispersibility and strong optical absorption properties for SELDI application. Compared with pristine CNT, graphene, GO, and CHCA, GONRs gave the highest MS signals in detection of environmental pollutants. In addition, the GONRs prepared from wide CNTs performed better than those from narrow CNTs.
Functionalized graphene The aims of functionalization of graphene mainly include:

1. To enhance the LDI efficiency (e.g., N-doping [87] and modification with SA [88])

2. To improve the selectivity of the SELDI probe [89-91]

3. To endow graphene with multiple functions (e.g., enzyme [92-95])

Zhang et al. [96] developed a highly efficient and visual method for glycan enrichment by using 1-pyrenebutyryl chloride functionalized GO (PCGO) and identification by direct MALDI-TOF MS analysis. Glycan was captured by reversible covalent bond formation between the hydroxyl groups of glycan and acyl chloride groups in GO introduced by $\pi-\pi$ stacking of 1-pyrenebutyryl chloride on the GO surface. The large specific surface area of free PCGO and heavy functionalization of highly active 1-pyrenebutyryl chloride improved the efficiency of enrichment.

Liu et al. [90] developed antibody-functionalized GONR (GONR-PEG-Ab) as a SELDI probe for selective enrichment and MS detection of small molecules in complex media. As the antibody can recognize and specifically bind with the antigen, GONRs modified with antibody can greatly improve the specificity of the probe. The probes combined the specificity of an antibody and the exceptional properties of GONRs, thus providing a high-throughput analysis and rapid screening of small molecules in complex media without any complicated sample preparation.

Graphene-based composite materials Graphene is often used combined with other materials to achieve better LDI efficiency or easy operations. These strategies include:

1. Hybridization with other nanomaterials to obtain better selectivity for specific analytes (e.g., with $\mathrm{TiO}_{2}$ for phosphopeptides [97-100]; poly(methyl methacrylate) for peptides [101])

2. Formation of composite materials or multilayered films to further enhance the LDI efficiency on the basis of synergistic effects (e.g., with MWCNTs [102-104], metal nanoparticles [105-108], and silica [109-111])

3. Modification with magnetic nanoparticles to make the materials responsible for the external magnetic field $[91,99,103,112-119]$

Liu et al. [112] demonstrated graphene-encapsulated magnetic microspheres $\left(\mathrm{Fe}_{3} \mathrm{O}_{4} @ \mathrm{SiO}_{2} @ \mathrm{G}\right)$ in enrichment and desalting of proteins and peptides for their subsequent MALDI-TOF MS analysis. Owing to the high adsorption capacity of graphene for biomolecules, $\mathrm{Fe}_{3} \mathrm{O}_{4} @ \mathrm{SiO}_{2} @ \mathrm{G}$ showed excellent performance in enhancement of MALDI-TOF MS signals of proteins and peptides in highly saline solutions. 
Fig. 3 Scheme showing a procedures for the synthesis of GONRs and $\mathbf{b}$ detection of small molecules by SELDI-TOF MS using GONRs as a probe. In a the blue spots indicate the oxidation sites in GONRs

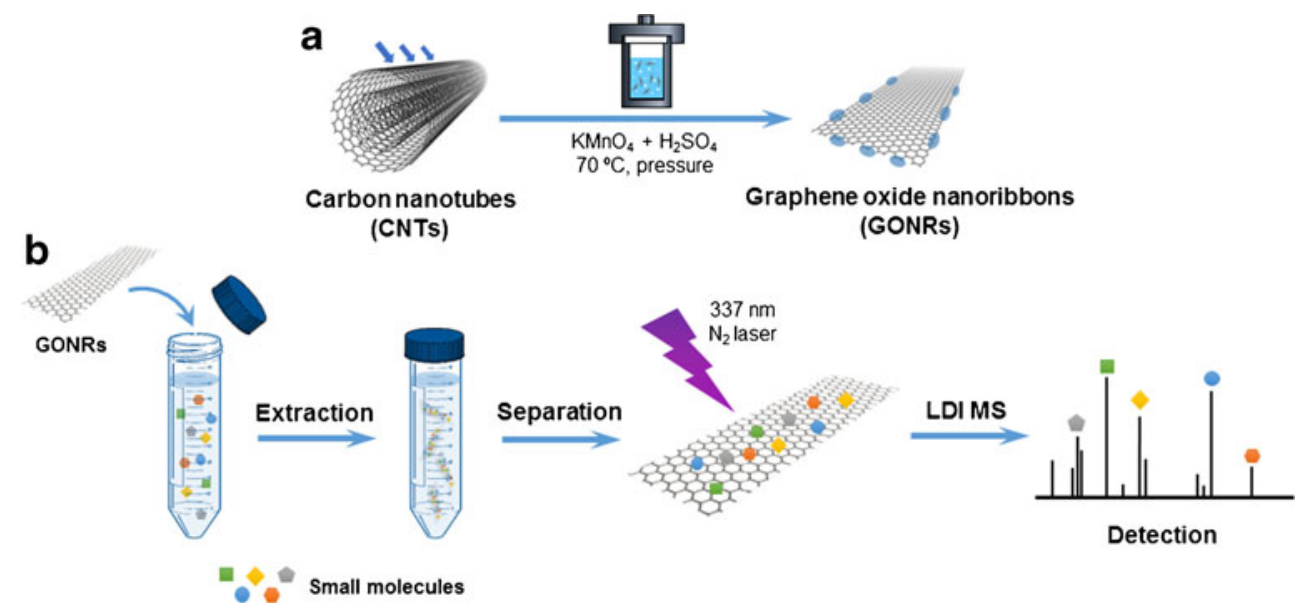

Yan et al. [120] reported an IMAC (immobilized metal ion affinity chromatography) material with polydopamine coated on the surface of graphene and functionalized with titanium ions ( $\left.\mathrm{Ti}^{4+}-\mathrm{G} @ \mathrm{PD}\right)$ as an immobilized metal ion affinity chromatography platform for phosphoproteome followed by MALDI-TOF MS. In this approach, the application of the $\mathrm{Ti}^{4+}$-G@PD material enhanced hydrophilicity and biological compatibility. Compared to $\mathrm{Ti}^{4+}-\mathrm{Fe}_{3} \mathrm{O}_{4} @$ polydopamine microspheres $\left(\mathrm{Ti}^{4+}-\mathrm{Fe}_{3} \mathrm{O}_{4} @ \mathrm{PD}\right)$, the $\mathrm{Ti}^{4+}-\mathrm{G} @ \mathrm{PD}$ material exhibited better specificity, sensitivity, and recovery. The replacement of $\mathrm{Fe}_{3} \mathrm{O}_{4}$ by graphene improved the phosphopeptide enrichment performance.

\section{Other forms of carbon nanomaterials}

Nanodiamond Nanodiamond (normal size $3-10 \mathrm{~nm}$ ) is another member of the carbon family that shows many interesting properties like optical absorption, chemical stability, biocompatibility, and low biotoxicity. Wei et al. [121] reported the use of nanodiamond as inorganic substrates for the MALDI target and developed an effective and useful approach for quantification and identification of proteins. Owing to the high absorbability of laser energy, nanodiamond could enhance the sensitivity by three to four times compared to conventional MALDI sample preparation methods. Moreover, nanodiamond showed good tolerance for salt (up to $500 \mathrm{mM} \mathrm{NaCl}$ ). Besides, good reproducibility ( $\mathrm{RSD}<11.8 \%$ ) among sample spots was achieved with nanodiamond as a matrix.

Nanodiamond is also an excellent platform for protein adsorption and immobilization. Hussain et al. [122] employed functionalized diamond nanopowder as IMAC and reversed phase to enrich phosphopeptides from standard casein $(\alpha, \beta$, k) as well as real samples like non-fat milk, egg yolk, and serum for MALDI-TOF MS analysis. Diamond nanopowder was applied as a separation medium with multifunctional use to cancer protein profiling for diagnosis and biomarker identification.
Carbon nanofibers Carbon nanofibers (CNFs) are fibers with diameters of 100-200 nm, lengths of 5-20 $\mu \mathrm{m}$, and typically carbonaceous structures comprising stacked graphite layers. CNFs have been used as gas adsorbents and catalyst supports owing to their large specific surface, high chemical stability, and unique mechanical properties.

Greiderer et al. [123] reported CNF derivatives as carrier materials for protein profiling in MELDI for the enrichment and screening of biofluids. Owing to their high surface area, CNFs allowed effective enrichment of analytes without prior albumin and immunoglobulin depletion. High protein-binding capacity ( $2000 \mu \mathrm{g} / \mathrm{mL}$ for insulin) and high sensitivities (LOD was $50 \mathrm{fmol} / \mu \mathrm{L}$ for insulin) were obtained.

Carbon nanodots Carbon nanodots (C-dots) are a newly emerged member of the carbon nanomaterial family. They have well-defined, nearly isotropic shapes together with their ultrafine dimensions, tunable surface functionalities, and biocompatibility.

Chen et al. [124] reported the application of C-dots as a matrix for the analysis of low-mass molecules by MALDITOF MS in both positive and negative ion modes and quantification of glucose and uric acid in real samples. A wide range of small molecules including amino acids, peptides, fatty acids, $\beta$-agonists, and neutral oligosaccharides were analyzed using $\mathrm{C}$-dots as matrix. In comparison with different carbon materials including graphene, CNT, C60, and graphite, $\mathrm{C}$-dots produced the highest sensitivity. The LOD for octadecanoic acid was $0.2 \mathrm{fmol}$.

Gedda et al. [125] reported citric acid-derived C-dots as a matrix for the detection of the anti-inflammatory drug mefenamic acid (MFA) by SELDI-TOF MS. Compared with DHB, C-dots generated less background signals and fragmentation of MFA. The LOD of MFA in serum was 0.51 and $0.46 \mathrm{ng}$ in positive and negative ion mode, respectively. The success of C-dots as matrix was ascribed to the following reasons: 
1. Low background interference in low-mass range.

2. Applicable in both positive and negative ion modes, thus providing more molecular information.

3. The abundant carboxylic acid groups on the surface of Cdots could facilitate the co-crystallization with analytes.

4. The small size $(\sim 3 \mathrm{~nm})$ of C-dots could reduce the coverage and make the analytes easy to desorb. In addition, the simple preparation, high stability, low toxicity, and low cost are also favorable for its applications.

Carbon nanohorns Carbon nanohorns (CNHs) are graphitic cone-shaped horns with closed ends. Similar to other graphitic nanomaterials (e.g., CNTs and graphene), CNHs have large surface area and high energy transfer efficiency. Furthermore, the special shape endows $\mathrm{CNHs}$ with plentiful inner nanospaces and extensive sites for functionalization after chemical oxidation. Ma et al. [126] demonstrated the use of CNHs as a matrix for SALDI MS analysis of small biological molecules with high sensitivity and low background interference. They also showed the modification of $\mathrm{CNHs}$ with aptamer to obtain a selective assay for adenosine triphosphate (ATP) in biological samples with an LOD of $1.0 \mu \mathrm{M}$.

\section{Conclusions and perspectives}

In summary, we have reviewed recent applications of carbon nanomaterials in LDI MS analysis. Carbon nanomaterials can play multiple roles in LDI MS. First, they can used as new matrices in MALDI MS to offer high LDI efficiency and high sensitivity. Second, carbon nanomaterials as matrices can reduce MS background noise over a wide mass range. This feature expands the application target of MALDI MS from large molecules to small molecules. Third, carbon nanomaterials are also a class of highly efficient adsorbents for analyte extraction and enrichment. Combination of the adsorption properties of carbon nanomaterials with their high performance in LDI can generate new SELDI techniques and increase the analytical sensitivity. Modification of carbon nanomaterials with functional groups can further improve the selectivity of detection. Conclusively, the application of carbon nanomaterials in LDI MS has opened a new vista for MS technology.

At the same time, it is important to recognize that many challenges still remain in the application of carbon nanomaterials in LDI MS. Most of the newly developed methods have only been evaluated in the laboratory and their application potentials in complex real samples require further verification. In our opinion, the future studies in this area should pay more attention to the following points:
1. Technical improvements in the purification and refinement of the carbon nanomaterials are required to offer more reliable analytical results and better reproducibility (especially inter-laboratory and long-term reproducibility). This actually is a universal problem for the application of nanomaterials in analytical science. New methods are also needed to recycle the materials after use.

2. Studies on the application of MALDI MS in quantitative analysis need to be strengthened. Since carbon nanomaterials can form more homogeneous matrices than conventional materials to provide more sensitive and precise measurement, we are looking forward to seeing more quantitative applications of MALDI MS using carbon nanomaterials as matrices or probes.

3. Safer techniques are demanded to immobilize nanomaterials on the MALDI target to prevent possible contamination of the ion source under vacuum without sacrifice in analytical performance.

4. More studies on the mechanism of carbon nanomaterialenhancing LDI process are desired to establish general guidelines for the selection of carbon nanomaterials or modification strategies with regards to different target analytes.

5. Stronger capability to direct analysis of complex real samples without complicated sample pretreatment procedures is highly valued for newly developed MS methods. Only in this way will the new methods really become practical tools in the framework of modern analytical science.

Acknowledgments The authors acknowledge support from the Chinese Academy of Sciences (No. XDB14010400), the National Basic Research Program of China (2015CB931903, 2015CB932003), and the National Natural Science Foundation of China (No. 21377141, 21422509, 91543104). Q. Liu also acknowledges the support from the Youth Innovation Promotion Association of CAS.

\section{Compliance with ethical standards}

Conflict of interest The authors declare no conflict of interest.

\section{References}

1. Karas M, Hillenkamp F. Laser desorption ionization of proteins with molecular masses exceeding 10,000 daltons. Anal Chem. 1988;60:2299-301.

2. Tanaka K, Waki H, Ido Y, Akita S, Yoshida Y, Yoshida T, et al. Protein and polymer analyses up to $\mathrm{m} / \mathrm{z} 100000$ by laser ionization time-of-flight mass spectrometry. Rapid Commun Mass Spectrom. 1988;2:151-3.

3. Lim AY, Ma J, Boey YCF. Development of nanomaterials for SALDI-MS analysis in forensics. Adv Mater. 2012;24:4211-6.

4. Zhang J, Li Z, Zhang C, Feng B, Zhou Z, Bai Y, et al. Graphitecoated paper as substrate for high sensitivity analysis in ambient 
surface-assisted laser desorption/ionization mass spectrometry. Anal Chem. 2012;84:3296-301.

5. Borisov RS, Polovkov NY, Zhilyaev DI, Esparza CA, Zaikin VG. Combination of graphite-assisted laser desorption/ionization (GALDI) mass spectrometry with thin layer chromatography. J Anal Chem. 2014;69:1351-5.

6. Kawasaki H, Shimomae Y, Watanabe T, Arakawa R. Desorption/ ionization on porous silicon mass spectrometry (DIOS-MS) of perfluorooctane sulfonate (PFOS). Colloids Surf A Physicochem Eng Asp. 2009;347:220-4.

7. Chen S, Chen L, Wang J, Hou J, He Q, Ja L, et al. 2,3,4,5Tetrakis(3',4'-dihydroxylphenyl)thiophene: a new matrix for the selective analysis of low molecular weight amines and direct determination of creatinine in urine by MALDI-TOF MS. Anal Chem. 2012;84:10291-7.

8. Wu H-P, Yu C-J, Lin C-Y, Lin Y-H, Tseng W-L. Gold nanoparticles as assisted matrices for the detection of biomolecules in a high-salt solution through laser desorption/ionization mass spectrometry. J Am Soc Mass Spectrom. 2009;20:875-82.

9. Chiang C-K, Chiang M-C, Lin Z-H, Lan G-Y, Lin Y-W, Chang HT. Nanomaterial-based surface-assisted laser desorption/ionization mass spectrometry of peptides and proteins. J Am Soc Mass Spectrom. 2010;21:1204-7.

10. Tang N, Tornatore P, Weinberger SR. Current developments in SELDI affinity technology. Mass Spectrom Rev. 2004;23:34-44.

11. Zhang BT, Zheng XX, Li HF, Lin JM. Application of carbonbased nanomaterials in sample preparation: a review. Anal Chim Acta. 2013;784:1-17.

12. Liu Q, Shi J, Jiang G. Application of graphene in analytical sample preparation. TrAC Trends Anal Chem. 2012;37:1-11.

13. Liang XJ, Liu SJ, Wang S, Guo Y, Jiang SX. Carbon-based sorbents: carbon nanotubes. J Chromatogr A. 2014;1357:53-67.

14. Najam-ul-Haq M, Rainer M, Szabo Z, Vallant R, Huck CW, Bonn GK. Role of carbon nano-materials in the analysis of biological materials by laser desorption/ionization-mass spectrometry. $\mathrm{J}$ Biochem Biophys Methods. 2007;70:319-28.

15. Rainer M, Najam-ul-Haq M, Huck CW, Vallant RM, Heigl N, Hahn H, et al. Carbon based sample supports and matrices for laser desorption/ionization mass spectrometry. Recent Pat Nanotechnol. 2007;1:113-9.

16. Scida K, Stege PW, Haby G, Messina GA, Garcia CD. Recent applications of carbon-based nanomaterials in analytical chemistry: critical review. Anal Chim Acta. 2011;691:6-17.

17. Kong XL, Huang Y. Applications of graphene in mass spectrometry. J Nanosci Nanotechnol. 2014;14:4719-32.

18. Lei C, Qian K, Noonan O, Nouwensa A, Yu CZ. Applications of nanomaterials in mass spectrometry analysis. Nanoscale. 2013;5: 12033-42.

19. Guo Z, Ganawi AA, Liu Q, He L. Nanomaterials in mass spectrometry ionization and prospects for biological application. Anal Bioanal Chem. 2006;384:584-92.

20. Li L, Xu L, Li Z, Bai Y, Liu H. Novel nanomaterials used for sample preparation for protein analysis. Anal Bioanal Chem. 2014;406:35-47.

21. Liu Q, Zhou QF, Jiang GB. Nanomaterials for analysis and monitoring of emerging chemical pollutants. TrAC Trends Anal Chem. 2014;58:10-22.

22. Hopwood FG, Michalak L, Alderdice DS, Fisher KJ, Willett GD. C-60-assisted laser desorption/ionization mass-spectrometry in the analysis of phosphotungstic acid. Rapid Commun Mass Spectrom. 1994;8:881-5.

23. Michalak L, Fisher KJ, Alderdice DS, Jardine DR, Willett GD. C60-assisted laser desorption-ionization mass-spectrometry. Org Mass Spectrom. 1994;29:512-5.

24. Shiea J, Huang J-P, Teng C-F, Jeng J, Wang LY, Chiang LY. Use of a water-soluble fullerene derivative as precipitating reagent and matrix-assisted laser desorption/ionization matrix to selectively detect charged species in aqueous solutions. Anal Chem. 2003;75:3587-95.

25. Vallant RM, Szabo Z, Trojer L, Najam-ul-Haq M, Rainer M, Huck $\mathrm{CW}$, et al. A new analytical material-enhanced laser desorption ionization (MELDI) based approach for the determination of low-mass serum constituents using fullerene derivatives for selective enrichment. J Proteome Res. 2007;6:44-53.

26. Vallant RM, Szabo Z, Bachmann S, Bakry R, Najam-ul-Haq M, Rainer M, et al. Development and application of C60-fullerene bound silica for solid-phase extraction of biomolecules. Anal Chem. 2007;79:8144-53.

27. Böddi K, Takátsy A, Szabó S, Markó L, Márk L, Wittmann I, et al. Use of fullerene-, octadecyl-, and triaconthyl silica for solid phase extraction of tryptic peptides obtained from unmodified and in vitro glycated human serum albumin and fibrinogen. J Sep Sci. 2009;32:295-308.

28. Szabo Z, Vallant RM, Takatsy A, Bakry R, Najam-ul-Haq M, Rainer $\mathrm{M}$, et al. Laser desorption/ionization mass spectrometric analysis of small molecules using fullerene-derivatized silica as energy-absorbing material. J Mass Spectrom. 2010;45:545-52.

29. Chen H, Qi D, Deng C, Yang P, Zhang X. Preparation of C60functionalized magnetic silica microspheres for the enrichment of low-concentration peptides and proteins for MALDI-TOF MS analysis. Proteomics. 2009;9:380-7.

30. Havel J, Soto-Guerrero J. Matrix assisted laser desorption ionization (MALDI) and laser desorption ionization (LDI) mass spectrometry for trace uranium determination: the use of C-60fullerene as a matrix. J Radioanal Nucl Chem. 2005;263:489-92.

31. Deacon GB, Field LD, Fisher K, Jaroschik F, Kay DL, Maschmeyer T, et al. Fullerene matrices in the MALDI-TOF mass spectroscopic characterisation of organometallic compounds. J Organomet Chem. 2014;751:482-92.

32. Iijima S. Helical microtubules of graphitic carbon. Nature. 1991;354:56-8.

33. Xu SY, Li YF, Zou HF, Qiu JS, Guo Z, Guo BC. Carbon nanotubes as assisted matrix for laser desorption/ionization time-offlight mass spectrometry. Anal Chem. 2003;75:6191-5.

34. Hsu W-Y, Lin W-D, Hwu W-L, Lai C-C, Tsai F-J. Screening assay of very long chain fatty acids in human plasma with multiwalled carbon nanotube-based surface-assisted laser desorption/ ionization mass spectrometry. Anal Chem. 2010;82:6814-20.

35. Pan CS, Xu SY, Zou HF, Guo Z, Zhang Y, Guo BC. Carbon nanotubes as adsorbent of solid-phase extraction and matrix for laser desorption/ionization mass spectrometry. J Am Soc Mass Spectrom. 2005;16:263-70.

36. Ren SF, Zhang L, Cheng ZH, Guo YL. Immobilized carbon nanotubes as matrix for MALDI-TOF-MS analysis: applications to neutral small carbohydrates. J Am Soc Mass Spectrom. 2005;16: 333-9.

37. Zhang J, Wang HY, Guo YL. Amino acids analysis by MALDI mass spectrometry using carbon nanotube as matrix. Chin J Chem. 2005;23:185-9.

38. Shin SJ, Choi DW, Kwak HS, Lim GI, Choi YS. Matrix-free laser desorption/ionization on vertically aligned carbon nanotube arrays. Bull Korean Chem Soc. 2006;27:581-3.

39. Gholipour Y, Nonami H, Erra-Balsells R. In situ analysis of plant tissue underivatized carbohydrates and on-probe enzymatic degraded starch by matrix-assisted laser desorption/ionization timeof-flight mass spectrometry by using carbon nanotubes as matrix. Anal Biochem. 2008;383:159-67.

40. Ye N. Protein profiles of human serum by SELDI-TOF-MS with multiwalled carbon nanotubes as absorbent. Anal Lett. 2008;41: 2554-63.

41. Pan CS, Xu SY, Hu LG, Su XY, Ou JJ, Zou HF, et al. Using oxidized carbon nanotubes as matrix for analysis of small 
molecules by MALDI-TOF MS. J Am Soc Mass Spectrom. 2005;16:883-92.

42. $\mathrm{Hu} \mathrm{L}$, Jiang $\mathrm{G}, \mathrm{Xu} \mathrm{S}$, Pan $\mathrm{C}$, Zou H. Monitoring enzyme reaction and screening enzyme inhibitor based on MALDI-TOF-MS platform with a matrix of oxidized carbon nanotubes. J Am Soc Mass Spectrom. 2006;17:1616-9.

43. Wang C-H, Li J, Yao S-J, Guo Y-L, Xia X-H. High-sensitivity matrix-assisted laser desorption/ionization Fourier transform mass spectrometry analyses of small carbohydrates and amino acids using oxidized carbon nanotubes prepared by chemical vapor deposition as matrix. Anal Chim Acta. 2007;604:158-64.

44. Shrivas K, Wu H-F. Oxidized multiwalled carbon nanotubes for quantitative determination of cationic surfactants in water samples using atmospheric pressure matrix-assisted laser desorption/ ionization mass spectrometry. Anal Chim Acta. 2008;628:198 203.

45. Carroccio SC, Curcuruto G, Dintcheva NT, Gambarotti C, Coiai $\mathrm{S}$, Filippone G. Using matrix-assisted laser desorption/ionization time-of-flight mass spectrometry for the characterization of functionalized carbon nanotubes. Rapid Commun Mass Spectrom. 2013;27:1359-66.

46. Shrivas K, Wui H-F. Functionalized-multiwalled carbon nanotubes as a preconcentrating probe for rapid monitoring of cationic dyestuffs in environmental water using AP-MALDI/MS. J Sep Sci. 2008;31:3603-11.

47. Ren SF, Guo YL. Oxidized carbon nanotubes as matrix for matrixassisted laser desorption/ionization time-of-flight mass spectrometric analysis of biomolecules. Rapid Commun Mass Spectrom. 2005;19:255-60.

48. Hu LG, Xu SY, Pan CS, Yuan CG, Zou HF, Jiang GB. Matrixassisted laser desorption/ionization time-of-flight mass spectrometry with a matrix of carbon nanotubes for the analysis of lowmass compounds in environmental samples. Environ Sci Technol. 2005;39:8442-7.

49. Najam-ul-Haq M, Rainer M, Schwarzenauer T, Huck CW, Bonn GK. Chemically modified carbon nanotubes as material enhanced laser desorption ionisation (MELDI) material in protein profiling. Anal Chim Acta. 2006;561:32-9.

50. S-f R, Guo Y-1. Carbon nanotubes (2,5-dihydroxybenzoyl hydrazine) derivative as $\mathrm{pH}$ adjustable enriching reagent and matrix for MALDI analysis of trace peptides. J Am Soc Mass Spectrom. 2006; 17:1023-7.

51. Lee J, Kim Y-K, Min D-H. Laser desorption/ionization mass spectrometric assay for phospholipase activity based on graphene oxide/carbon nanotube double-layer films. J Am Chem Soc. 2010;132:14714-7.

52. Shrivas $\mathrm{K}, \mathrm{Wu} \mathrm{H}-\mathrm{F}$. Multifunctional nanoparticles composite for MALDI-MS: Cd2+-doped carbon nanotubes with CdS nanoparticles as the matrix, preconcentrating and accelerating probes of microwave enzymatic digestion of peptides and proteins for direct MALDI-MS analysis. J Mass Spectrom. 2010;45:1452-60.

53. Yan Y, Zheng Z, Deng C, Zhang X, Yang P. Selective enrichment of phosphopeptides by titania nanoparticles coated magnetic carbon nanotubes. Talanta. 2014;118:14-20.

54. Zhang Y, Cao W, Liu M, Yang S, Wu H, Lu H, et al. Immobilization of trypsin on water-soluble dendrimer-modified carbon nanotubes for on-plate proteolysis combined with MALDI-MS analysis. Mol Biosyst. 2010;6:1447-9.

55. Ceglowski M, Schroeder G. Laser desorption/ionization mass spectrometric analysis of surfactants on functionalized carbon nanotubes. Rapid Commun Mass Spectrom. 2013;27:258-64.

56. Huang D, Wang X, Deng C. Enrichment and determination of crotonaldehyde using magnetic multiwalled carbon nanotubes as an adsorbent and a matrix for matrix-assisted laser desorption/ ionization time-of-flight mass spectrometry. Rapid Commun Mass Spectrom. 2013;27:847-50.
57. Shi C, Deng C, Zhang X, Yang P. Synthesis of highly waterdispersible polydopamine-modified multiwalled carbon nanotubes for matrix-assisted laser desorption/oonization mass spectrometry analysis. ACS Appl Mater Interf. 2013;5:7770-6.

58. He X-M, Zhu G-T, Yin J, Zhao Q, Yuan B-F, Feng Y-Q. Electrospun polystyrene/oxidized carbon nanotubes film as both sorbent for thin film microextraction and matrix for matrixassisted laser desorption/ionization time-of-flight Mass spectrometry. J Chromatogr A. 2014;1351:29-36.

59. Li X-S, Wu J-H, Xu L-D, Zhao Q, Luo Y-B, Yuan B-F, et al. A magnetite/oxidized carbon nanotube composite used as an adsorbent and a matrix of MALDI-TOF-MS for the determination of benzo a pyrene. Chem Commun. 2011;47:9816-8.

60. Novoselov KS, Geim AK, Morozov SV, Jiang D, Zhang Y, Dubonos SV, et al. Electric field effect in atomically thin carbon films. Science. 2004;306:666-9.

61. Park S, Ruoff RS. Chemical methods for the production of graphenes. Nat Nanotechnol. 2009;4:217-24.

62. Zhu YW, Murali S, Cai WW, Li XS, Suk JW, Potts JR, et al. Graphene and graphene oxide: synthesis, properties, and applications. Adv Mater. 2010;22:3906-24.

63. Dong XL, Cheng JS, Li JH, Wang YS. Graphene as a novel matrix for the analysis of small molecules by MALDI-TOF MS. Anal Chem. 2010;82:6208-14.

64. Hua P-Y, Manikandan M, Abdelhamid HN, Wu H-F. Graphene nanoflakes as an efficient ionizing matrix for MALDI-MS based lipidomics of cancer cells and cancer stem cells. J Mater Chem B. 2014;2:7334-43.

65. Cho D, Hong S, Shim S. Few layer graphene matrix for matrixassisted laser desorption/ionization time-of-flight mass spectrometry. J Nanosci Nanotechnol. 2013;13:5811-3.

66. Tang LAL, Wang JZ, Loh KP. Graphene-based SELDI probe with ultrahigh extraction and sensitivity for DNA oligomer. J Am Chem Soc. 2010;132:10976-7.

67. Lu M, Lai Y, Chen G, Cai Z. Laser desorption/ionization on the layer of graphene nanoparticles coupled with mass spectrometry for characterization of polymers. Chem Commun. 2011;47: 12807-9.

68. Chang C, Li X, Bai Y, Xu G, Feng B, Liao Y, et al. Graphene matrix for signal enhancement in ambient plasma assisted laser desorption ionization mass spectrometry. Talanta. 2013;114:54-9.

69. Lu M, Lai Y, Chen G, Cai Z. Matrix interference-free method for the analysis of small molecules by using negative ion laser desorption/ionization on graphene flakes. Anal Chem. 2011;83: 3161-9.

70. Wan D, Gao MX, Wang YH, Zhang P, Zhang XM. A rapid and simple separation and direct detection of glutathione by gold nanoparticles and graphene-based MALDI-TOF-MS. J Sep Sci. 2013;36:629-35.

71. Zhou XZ, Wei YY, He QY, Boey F, Zhang QC, Zhang H. Reduced graphene oxide films used as matrix of MALDI-TOF-MS for detection of octachlorodibenzo-p-dioxin. Chem Commun. 2010;46:6974-6.

72. Zhang J, Dong XL, Cheng JS, Li JH, Wang YS. Efficient analysis of non-polar environmental contaminants by MALDI-TOF MS with graphene as matrix. J Am Soc Mass Spectrom. 2011;22: 1294-8.

73. Liu JY, Liu Y, Gao MX, Zhang XM. High throughput detection of tetracycline residues in milk using graphene or graphene oxide as MALDI-TOF MS matrix. J Am Soc Mass Spectrom. 2012;23: 1424-7.

74. Liu Y, Liu J, Deng C, Zhang X. Graphene and graphene oxide: two ideal choices for the enrichment and ionization of long-chain fatty acids free from matrix-assisted laser desorption/ionization matrix interference. Rapid Commun Mass Spectrom. 2011;25: 3223-34. 
75. Liu Y, Liu JY, Yin P, Gao MX, Deng CH, Zhang XM. High throughput identification of components from traditional Chinese medicine herbs by utilizing graphene or graphene oxide as MALDI-TOF-MS matrix. J Mass Spectrom. 2011;46:804-15.

76. Liu CW, Chien MW, Su CY, Chen HY, Li LJ, Lai CC. Analysis of flavonoids by graphene-based surface-assisted laser desorption/ ionization time-of-flight mass spectrometry. Analyst. 2012;137: 5809-16.

77. Zhang S, Ding L, Li S, Kong X, Huang Y. Use of graphene as a matrix to minimize reduction in the process of matrix-assisted laser desorption/ionization. Rapid Commun Mass Spectrom. 2013;27:1278-82.

78. Abdelhamid HN, Wu H-F. A method to detect metal-drug complexes and their interactions with pathogenic bacteria via graphene nanosheet assist laser desorption/ionization mass spectrometry and biosensors. Anal Chim Acta. 2012;751:94-104.

79. Abdelhamid HN, Wu H-F. Ultrasensitive, rapid, and selective detection of mercury using graphene assisted laser desorption/ ionization mass spectrometry. J Am Soc Mass Spectrom. 2014;25:861-8.

80. Bai H, Pan Y, Tong W, Zhang W, Ren X, Tian F, et al. Graphene based soft nanoreactors for facile "one-step" glycan enrichment and derivatization for MALDI-TOF-MS analysis. Talanta. 2013;117:1-7.

81. Liu Y, Li Y, Liu J, Deng C, Zhang X. High throughput enzyme inhibitor screening by functionalized magnetic carbonaceous microspheres and graphene oxide-based MALDI-TOF-MS. J Am Soc Mass Spectrom. 2011;22:2188-98.

82. Huang R-C, Chiu W-J, Li Y-J, Huang C-C. Detection of microRNA in tumor cells using exonuclease III and graphene oxide-regulated signal amplification. ACS Appl Mater Interf. 2014;6:21780-7.

83. Kim Y-K, Min D-H. The structural influence of graphene oxide on its fragmentation during laser desorption/ionization mass spectrometry for efficient small-molecule analysis. Chem Eur J. 2015;21:7217-23.

84. Liu Q, Cheng MT, Jiang GB. Mildly oxidized graphene: facile synthesis, characterization, and application as a matrix in MALDI mass spectrometry. Chem Eur J. 2013;19:5561-5.

85. Wang J, Liu Q, Gao Y, Wang Y, Guo L, Jiang G. High-throughput and rapid screening of low-mass hazardous compounds in complex samples. Anal Chem. 2015;87:6931-6.

86. Liu Q, Cheng MT, Wang J, Jiang GB. Graphene oxide nanoribbons: improved synthesis and application in MALDI mass spectrometry. Chem Eur J. 2015;21:5594-9.

87. Min QH, Zhang XX, Chen XQ, Li SY, Zhu JJ. N-doped graphene: an alternative carbon-based matrix for highly efficient detection of small molecules by negative ion MALDI-TOF MS. Anal Chem. 2014;86:9122-30.

88. Abdelhamid HN, Wu H-F. Synthesis of a highly dispersive sinapinic acid@graphene oxide (SA@GO) and its applications as a novel surface assisted laser desorption/ionization mass spectrometry for proteomics and pathogenic bacteria biosensing. Analyst. 2015;140:1555-65.

89. Gulbakan B, Yasun E, Shukoor MI, Zhu Z, You M, Tan X, et al. A dual platform for selective analyte enrichment and ionization in mass spectrometry using aptamer-conjugated graphene oxide. J Am Chem Soc. 2010;132:17408-10.

90. Wang J, Cheng M, Zhang Z, Guo L, Liu Q, Jiang G. An antibodygraphene oxide nanoribbon conjugate as a surface enhanced laser desorption/ionization probe with high sensitivity and selectivity. Chem Commun. 2015;51:4619-22.

91. Xiong Y, Deng CH, Zhang XM. Development of aptamerconjugated magnetic graphene/gold nanoparticle hybrid nanocomposites for specific enrichment and rapid analysis of thrombin by MALDI-TOF MS. Talanta. 2014;129:282-9.
92. Xu GB, Chen XY, Hu JH, Yang PY, Yang D, Wei LM. Immobilization of trypsin on graphene oxide for microwaveassisted on-plate proteolysis combined with MALDI-MS analysis. Analyst. 2012;137:2757-61.

93. Jiao J, Miao A, Zhang X, Cai Y, Lu Y, Zhang Y, et al. Realization of on-tissue protein identification by highly efficient in situ digestion with graphene-immobilized trypsin for MALDI imaging analysis. Analyst. 2013;138:1645-8.

94. Jiang B, Yang K, Zhang L, Liang Z, Peng X, Zhang Y. Dendrimergrafted graphene oxide nanosheets as novel support for trypsin immobilization to achieve fast on-plate digestion of proteins. Talanta. 2014;122:278-84.

95. Ren X, Bai H, Pan Y, Tong W, Qin P, Yan H, et al. A graphene oxide-based immobilized PNGase F reagent for highly efficient $\mathrm{N}$-glycan release and MALDI-TOF MS profiling. Anal Methods. 2014;6:2518.

96. Zhang W, Han H, Bai H, Tong W, Zhang Y, Ying W, et al. A highly efficient and visualized method for glycan enrichment by self-assembling pyrene derivative functionalized free graphene oxide. Anal Chem. 2013;85:2703-9.

97. Lu J, Wang M, Li Y, Deng C. Facile synthesis of $\mathrm{TiO}_{2} /$ graphene composites for selective enrichment of phosphopeptides. Nanoscale. 2012;4:1577-80.

98. Tang LAL, Wang J, Lim TK, Bi X, Lee WC, Lin Q, et al. Highperformance graphene-titania platform for detection of phosphopeptides in cancer cells. Anal Chem. 2012;84:6693-700.

99. Lu J, Deng C, Zhang X, Yang P. Synthesis of $\mathrm{Fe}_{3} \mathrm{O}_{4} /$ graphene/ $\mathrm{TiO}_{2}$ composites for the highly selective enrichment of phosphopeptides from biological samples. ACS Appl Mater Interf. 2013;5:7330-4.

100. Shen Q, Yang M, Li L, Cheung H-Y. Graphene/TiO 2 nanocomposite based solid-phase extraction and matrix-assisted laser desorption/ionization time-of-flight mass spectrometry for lipidomic profiling of avocado (Persea americana Mill.). Anal Chim Acta. 2014;852:153-61.

101. Yin P, Zhao M, Deng C. High efficiency enrichment of lowabundance peptides by novel dual-platform graphene@SiO $\mathrm{Si}_{2} @$ PMMA. Nanoscale. 2012;4:6948-50.

102. Kim Y-K, Na H-K, Kwack S-J, Ryoo S-R, Lee Y, Hong S, et al. Synergistic effect of graphene oxide/MWCNT films in laser desorption/ionization mass spectrometry of small molecules and tissue imaging. ACS Nano. 2011;5:4550-61.

103. Shi C, Meng J, Deng C. Facile synthesis of magnetic graphene and carbon nanotube composites as a novel matrix and adsorbent for enrichment and detection of small molecules by MALDI-TOF MS. J Mater Chem. 2012;22:20778-85.

104. Kim YK, Min DH. Mechanistic study of laser desorption/ ionization of small molecules on graphene oxide multilayer films. Langmuir. 2014;30:12675-83.

105. Kawasaki H, Nakai K, Arakawa R, Athanassiou EK, Grass RN, Stark WJ. Functionalized graphene-coated cobalt nanoparticles for highly efficient surface-assisted laser desorption/ionization mass spectrometry analysis. Anal Chem. 2012;84:9268-75.

106. Kim YK, Min DH. Fabrication of alternating multilayer films of graphene oxide and carbon nanotube and its application in mechanistic study of laser desorption/ionization of small molecules. ACS Appl Mater Interf. 2012;4:2088-95.

107. Kim Y-K, Min D-H. Preparation of the hybrid film of poly(allylamine hydrochloride)-functionalized graphene oxide and gold nanoparticle and its application for laser-induced desorption/ionization of small molecules. Langmuir. 2012;28: 4453-8.

108. Kuo T-R, Wang D-Y, Chiu Y-C, Yeh Y-C, Chen W-T, Chen C-H, et al. Layer-by-layer thin film of reduced graphene oxide and gold nanoparticles as an effective sample plate in laser-induced 
desorption/ionization mass spectrometry. Anal Chim Acta. 2014;809:97-103.

109. Yin P, Wang Y, Li Y, Deng C, Zhang X, Yang P. Preparation of sandwich-structured graphene/mesoporous silica composites with C8-modified pore wall for highly efficient selective enrichment of endogenous peptides for mass spectrometry analysis. Proteomics. 2012;12:2784-91.

110. Abdelhamid HN, Wu B-S, Wu H-F. Graphene coated silica applied for high ionization matrix assisted laser desorption/ionization mass spectrometry: a novel approach for environmental and biomolecule analysis. Talanta. 2014;126:27-37.

111. Liu Q, Shi JB, Sun JT, Wang T, Zeng LX, Jiang GB. Graphene and graphene oxide sheets supported on silica as versatile and highperformance adsorbents for solid-phase extraction. Angew Chem Int Ed. 2011;50:5913-7.

112. Liu Q, Shi J, Cheng M, Li G, Cao D, Jiang G. Preparation of graphene-encapsulated magnetic microspheres for protein/ peptide enrichment and MALDI-TOF MS analysis. Chem Commun. 2012;48:1874-6.

113. Shi C, Meng J, Deng C. Enrichment and detection of small molecules using magnetic graphene as an adsorbent and a novel matrix of MALDI-TOF-MS. Chem Commun. 2012;48:2418-20.

114. Abdelhamid HN, Wu H-F. Multifunctional graphene magnetic nanosheet decorated with chitosan for highly sensitive detection of pathogenic bacteria. J Mater Chem B. 2013;1:3950-61.

115. Sha Y, Huang D, Zheng S, Deng C. Development of magnetic graphene as an adsorbent and matrix for selective enrichment and detection of crotonaldehyde in saliva by MALDI-TOF-MS. Anal Methods. 2013;5:4585-90.

116. Yin P, Sun N, Deng C, Li Y, Zhang X, Yang P. Facile preparation of magnetic graphene double-sided mesoporous composites for the selective enrichment and analysis of endogenous peptides. Proteomics. 2013;13:2243-50.

117. Zhao M, Deng C, Zhang X. Synthesis of polydopamine-coated magnetic graphene for $\mathrm{Cu}^{2+}$ immobilization and application to the enrichment of low-concentration peptides for mass spectrometry analysis. ACS Appl Mater Interf. 2013;5:13104-12.
118. Ye N, Xie Y, Shi P, Gao T, Ma J. Synthesis of magnetite/graphene oxide/chitosan composite and its application for protein adsorption. Mater Sci Eng C. 2014;45:8-14.

119. Zhang JG, Zhang L, Li RJ, Hu D, Ma NX, Shuang SM, et al. Magnetic graphene composites as both an adsorbent for sample enrichment and a MALDI-TOF MS matrix for the detection of nitropolycyclic aromatic hydrocarbons in PM2.5. Analyst. 2015;140:1711-6.

120. Yan Y, Zheng Z, Deng C, Li Y, Zhang X, Yang P. Hydrophilic polydopamine-coated graphene for metal ion immobilization as a novel immobilized metal ion affinity chromatography platform for phosphoproteome analysis. Anal Chem. 2013;85:8483-7.

121. Wei L-M, Xue Y, Zhou X-W, Jin H, Shi Q, Lu H-J, et al. Nanodiamond MALDI support for enhancing the credibility of identifying proteins. Talanta. 2008;74:1363-70.

122. Hussain D, Najam-ul-Haq M, Jabeen F, Ashiq MN, Athar M, Rainer M, et al. Functionalized diamond nanopowder for phosphopeptides enrichment from complex biological fluids. Anal Chim Acta. 2013;775:75-84.

123. Greiderer A, Rainer M, Najam-ul-Haq M, Vallant RM, Huck CW, Bonn GK. Derivatized graphitic nanofibres (GNF) as a new support material for mass spectrometric analysis of peptides and proteins. Amino Acids. 2009;37:341-8.

124. Chen S, Zheng H, Wang J, Hou J, He Q, Liu H, et al. Carbon nanodots as a matrix for the analysis of low-molecular-weight molecules in both positive- and negative-ion matrix-assisted laser desorption/ionization time-of-flight mass spectrometry and quantification of glucose and uric acid in real samples. Anal Chem. 2013;85:6646-52.

125. Gedda G, Pandey S, Bhaisare ML, Wu HF. Carbon dots as nanoantennas for anti-inflammatory drug analysis using surfaceassisted laser desorption/ionization time-of-flight mass spectrometry in serum. RSC Adv. 2014;4:38027-33.

126. Ma RN, Lu MH, Ding L, Ju HX, Cai ZW. Surface-assisted laser desorption/ionization mass spectrometric detection of biomolecules by using functional single-walled carbon nanohorns as the matrix. Chem Eur J. 2013;19:102-8. 